Int. J. Electrochem. Sci., 11 (2016) $4892-4908$

\title{
Distinctive Routs:Electrochemical and Spectrophotometric Studies and Dissociation Constants Determination of Some Aminopyridine Azo-Dye Derivatives in Aqueous Media
}

\author{
E.M. Mabrouk ${ }^{1}$, R.N. Felaly ${ }^{2}$ and E.H. El-Mossalamy ${ }^{1}$ \\ ${ }^{1}$ Chemistry Department, Faculty of Science, Benha University, Benha, Egypt. \\ ${ }^{2}$ Chemistry Department, Faculty of Applied Science, Umm Al-Qura University, Makkah Al- \\ Mukarrama, Saudi Arabia. \\ *E-mail: emmabrouk90@yahoo.com
}

doi: $10.20964 / 2016.06 .49$

Received: 11 December 2015 / Accepted: 23 January 2016 / Published: 4 May 2016

\begin{abstract}
The electrochemical behavior of some azo compounds derived from 2-amino-3-hydroxypyridine in Britton and Robinson buffer series containing 20\% (v/v) ethanol was investigated at the mercury electrode using distinctive techniques (DC, CV and DPP) to evaluate the effect of medium and substituents on the reduction process and suggestion of the electrode reaction mechanism. The obtained results indicated that these compounds were reduced undergo an irreversible 4-electron polarographic wave within the entire $\mathrm{pH}$ range leading to the cleavage of the $\mathrm{N}=\mathrm{N}$ center. $\mathrm{The}^{\mathrm{NO}} \mathrm{N}_{2}$ derivative is reduced via a single 8-electron wave and the hydroxylamine group is obtained. The CV data showed that a single cathodic peak is obtained at all $\mathrm{pH}$ representing the reduction of the azo center as well as the nitro group for azo compound (II). The total number of electrons involved in the reduction process was determined by controlled potential coulometry. The dissociation constants values $\left(\mathrm{pk}_{\mathrm{a}}\right)$ of these compounds were determined spectrophotometrically and potentiometrically at room temperature.
\end{abstract}

Keywords: 2-amino-3-hydroxypyridineazo dyes, Polarography, Cyclic voltammetry, Spectrophotometry, Potentiometry, Dissociation constants.

\section{$\underline{\text { FULL TEXT }}$}

(C) 2016 The Authors. Published by ESG (www.electrochemsci.org). This article is an open access article distributed under the terms and conditions of the Creative Commons Attribution license (http://creativecommons.org/licenses/by/4.0/). 